\title{
Residents' Opinion on Virus Mitigation: A Case of Barangay San Pablo, the Philippines
}

Cyndell Jzhaqiy Blett S. Carlet, Romel Andre S. Doria, Caesar Ean R. Imperial, Vanessa Kaye J. Liza *, Anamarie G. Valdez

Sultan Kudarat State University, the Philippines

* Correspondence: E-mail: vanessakayeliza@sksu.edu.ph

\section{A B S T R A C T S}

This study was engaged for assessing the approaches of the barangay officials in mitigating the virus spread in the area through the opinions and experiences of the residents. The study was directed to a new and relevant type of adversity for a virus outbreak that can test the capabilities of the leaders. We utilized phenomenology, wherein narratives have been gathered through interviews. We extracted 5 themes; Erring Situations, Awareness on Precautionary Measures, Approach among Residents, Inequality among Residents, and Discipline. The barangay officials have never failed in implementing necessary protocols. But the protocols may not be sufficient to attain victory. For instance, statements have suggested that constant evaluation through the area should be mandated, and most importantly, the barangay officials should essentially be the first to follow their implementations. Overall, this study impacted the residents by providing a platform to voice out the leadership they received during these trying times.

\begin{tabular}{l}
\hline A R T I C L E I N F O \\
\hline Article History: \\
Submitted/Received 15 Oct 2021 \\
First revised 25 Nov 2021 \\
Accepted 27 Nov 2021 \\
First available online 29 Nov 2021 \\
Publication date 01 Dec 2021 \\
\hline Keyword: \\
Barangay Officials, \\
Coronavirus disease, \\
Pandemic, \\
Virus Mitigation.
\end{tabular}

A R T I CLE IN F O

Submitted/Received 15 Oct 2021

First revised 25 Nov 2021

First available online 29 Nov 2021

Publication date $01 \mathrm{Dec} 2021$

Barangay Officials,

Virus Mitigation. 


\section{INTRODUCTION}

In December 2019, a disease named Covid-19 was introduced as a brand-new strain of Coronavirus, subsequently named SARS-CoV-2. It is also referred to as "2019 novel coronavirus" or "2019 n-CoV". This virus that is said to "hold a threat of starting a global pandemic" has gotten its first case in a Seafood Wholesale Wet Market in Wuhan, Hubei, China, with $66 \%$ of its staff proven present at the time. China was the first country to designate a regional curfew on cities in Hubei province as a security precaution.

A 76-day lockdown was imposed on Wuhan, Hubei Province's biggest city, with nearly 14 million people. Countries such as Italy (Lombardy and Veneto), Russia, India, and the Philippines utilized similar lockdowns in the following years. The lengths varied from 4 days in Turkey to over a year in Qatar. On Department of Health (DOH) of the Philippines on 30 January 2020 confirmed its first confirmed case in the country of the Novel Coronavirus with a 38-year-old female Chinese national (Harapan et al., 2020).

While on 7 March, the Philippines confirmed its first locally transmitted case of the Novel Coronavirus. Soon after, an Enhanced Community Quarantine (ECQ) was implemented, which lasted from the 20th day of March to the 30th day of April 2020, to essentially help contaminate the country's virus. And with the virus' continuous spread globally, the World Health Organization (WHO) declared the Novel Coronavirus, more commonly known as COVID-19 disease, officially a Global Pandemic on 12 March 2020.

On 16 April, Tacurong City recorded its first confirmed COVID-19 case, PH3269, a 38-yearold patient with a travel history in Davao City. And in August, the City Epidemiology and Surveillance Unit (CESU) confirmed its first local transmission of COVID-19 inside the city.

On September 20, information was received by both the City Health Officer and the PNP Station of Tacurong City that a resident of Purok Saranay, Barangay San Pablo, Tacurong City, was found positive for COVID-19 as a result of the RT PCR Test. This information triggered the Barangay San Pablo residents and neighboring barangays to perform more rigorous safety precautionary methods following the recent case in the area.

The circulating virus that has reached almost every country in the world directly proposed a threat to our society as a whole. From our health down to the economy, everything has been immensely disrupted by the ongoing pandemic. Educational, sports, spiritual, commercials, tourism, business, and other more institutions were forced to close and discontinue for a while.

High inflation and the increasing unemployment rate were experienced even by the most powerful countries, but these events have positively affected the environment. For instance, industrial waste emission has decreased to a large extent. Overall, the lockdowns enforced everywhere directly affected the GDP of each country in major economics, with approximated loss of $2 \%$ points in annual GDP growth each month (Chakraborty \& Maity, 2020).

From these unexpected and sudden events, we can feel the need for competent and wise leaders to lessen the impacts of this pandemic. Thus, this investigation was done to identify the experiences and opinions of the residents in Barangay San Pablo regarding the approaches used by the Barangay Officials in mitigating the spread of the virus and answering the one-grand question: "How did the barangay officials control the virus outbreak in the area?" The information gathered in this study would benefit both parties in keeping a proper and open communication and connection between the Barangay Officials and its residents. 


\section{METHODS}

This study employed a phenomenological descriptive qualitative research design using Cilesiz's (2011) method of Phenomenology. Using semi-structured interviews, the design gathered all narratives and identified themes to validate the residents' opinions. This study was conducted on specific households in Barangay San Pablo, Tacurong City. This study was fully conducted using online platforms depending on the participants' choice, as an adjustment for the limitations of the ongoing pandemic. After collecting the data through online platforms, the data gathered were analyzed using the phenomenological analysis method.

\subsection{Participants of the Study}

We used purposive sampling, in which participants meet predefined criteria, as their sampling technique. This study selected five residents of Brgy. San Pablo to be the participants that should be: (a) a resident of Barangay San Pablo, (b) a housewife, (c) a youth, (d) an employed worker.

\subsection{Data Gathering Instruments}

We identified the participants fitted in the study and set an interview to attain the appropriate data needed. Three serial in-depth phenomenological semi-structured interviews with each research participant should be appropriate to collect phenomenological data (DiGiacomo et al., 2015). As developed by Seidman, previous experience with the phenomenon of interest is assessed in the first interview, while the following interview is based on the current experience.

The third interview combines the information obtained from the previous two interviews to describe the individual's essential experience with the phenomenon. We asked for the participant's information, how did the Barangay control the virus outbreak in the area, what implemented levels of precautionary methods did the officials increased when a case of the virus hit the Barangay, what benefits did the residents receive in the middle of the pandemic, and what problems have hindered them with the Barangay.

\subsection{Data Gathering Procedure}

This study assigned a codename for every participant to help maintain the confidentiality of their identities. We ensured that all the personal data collected were kept confidential at all times. Then, to accumulate the data, we asked for permission to record the interview, which was beneficial. This study tried to adjust to the participants' comfort to gather the participants' most valuable data. And lastly, this study assured that all of the letters and the in-depth interview of the participants were distributed and done without meeting face-toface and taking advantage of online platforms as a modification with the ongoing pandemic.

\section{RESULTS AND DISCUSSION}

The study was conducted with five (5) residents of the Barangay San Pablo being the participants of the study. They are interviewed with the essence of answering the one grand question of the study: How did the barangay officials control the virus outbreak in the area? After interrogating the participants, this study analyzed the data gathered and generated five (5) emergent themes with each of their sub-theme/s. 
Erring Situations. Managing and maintaining the safety of the residents from the spreading covid-19 virus can only be achieved by implementing and mandating precautionary safety methods, limiting human movements, and offering assistance that the barangay officials can only do. These health protocol strategies are made to control the impact of the pandemic, but at the same time, should also consider the economic, social, religious, and cultural factors different from every person, community, or country (Dan-Nwaffor et al., 2020).

According to the participants of the study, there have been statements that say the barangay officials haven't done a good job in handling the situation in general. Specifically, some residents are mistreated, specific implemented methods are not done clearly and strictly, and some statements say the barangay officials themselves don't follow their implementations, so that doesn't show a good image for their residents.

Awareness of Precautionary Measures. It appears that the residents are quite aware of the precautionary measures implemented by the government in general. According to the participants, these implementations include the requirement of wearing face masks, the vital purpose of quarantine passes in the early months of the pandemic where lockdowns are implemented, curfew hours, and lockdowns and boundaries among specific households that currently have a present case of the virus. These precautionary measures are made for the safety and mitigation of the virus.

Approach Among Residents. Communication had always been a vital and crucial factor in achieving a goal, in this study, as a barangay. Be it with following the Higher Levels of the Government or being active in interacting with the residents. According to the answers of the participants, their barangay officials have been effective in disseminating information, they have been quite approachable for their residents, and they also have a good flow of communication with the higher levels of government, this implies that the Barangay Officials aren't just working hard on their own, but with the local authorities with them as well.

Inequality Among Residents. As the elected officials or leaders of the residents inside the barangay, they are subjected to lead with transparency and unbiasedness. Benefits are distributed to the residents to limit human contacts that can effectively contribute directly to the mitigation of the virus and to their safety as individuals. Unfortunately, the participants have revealed that the benefits seem to be insufficient for their needs. Moreover, they also stated that the benefits were distributed unfairly to the point that some residents never received any benefit.

Discipline. Implementations of precautionary measures and protocols don't immediately grant the assurance of safety to the community during the pandemic. According to Weymouth and Hartz-Karp (2019), there is a public consensus that in democracy, the system of government present in the Philippines, requires participation from their citizens as a step for successful governance including the public service of the leaders. But as revealed by the participants, even after learning the precautionary methods suggested by professionals and implemented by the barangay officials, some residents still decided to turn a blind eye to the implemented safety measures by the barangay officials and local authorities.

According to the results of Christian (2020), one proven reason behind the low obedience of society in Indonesia to the implemented health protocols was by underestimating the possible impact of the virus on their body, thinking that it will be just feel like a common flu, thus never realising the real benefits of these health protocols. The participants are disappointed to disclose that residents, especially in hidden households, don't follow the protocols, especially wearing face masks, when wandering outside their premises. 


\section{CONCLUSION}

The following was concluded according to the themes analyzed:

(i) The barangay officials are always approachable in terms of voicing out the resident's concerns. The barangay officials who are somewhat doing their job are the role models of their barangay.

(ii) Some of the benefits the residents received were not enough and were distributed unfairly. Some never received any benefits at all. The unfair distribution of benefits caused some misunderstandings between the residents and their officials.

(iii) Some residents still decided to turn a blind eye to the implemented safety measures by the Barangay Officials. Some residents did not follow some rules, precautionary methods, and curfew in the barangay.

(iv) The Barangay officials consistently implement the Precautionary Measures required by the higher levels of the government. They were required to wear face masks when wandering outside their homes, and a curfew was implemented, restricting residents from walking outside their homes during curfew hours.

(v) Overall, the Barangay Officials are found to have mishandled some situations. The residents are somewhat unsatisfied with how Barangay Officials manage the situation.

\section{ACKNOWLEDGMENT}

We would like to express their infinite gratitude to the following factors for making this study possible: research advisers, panel of examiners, participants of the study, and the institution - sultan kudarat state university - laboratory science high school.

\section{AUTHORS' NOTE}

The authors declare that there is no conflict of interest regarding the publication of this article. Authors confirmed that the paper was free of plagiarism.

\section{REFERENCES}

Chakraborty, I., and Maity, P. (2020). COVID-19 outbreak: Migration, effects on society, global environment, and prevention. Science of The Total Environment, 728, 138882.

Christian, A. (2021). Obedience towards health protocols during Covid-19 pandemic. SOSHUM: Jurnal Sosial dan Humaniora, 11(2), 201-210.

Cilesiz, S. (2011). A phenomenological approach to experiences with technology: Current state, promise, and future directions for research. Educational Technology Research and Development, 59(4), 487-510.

DiGiacomo, M., Lewis, J., Phillips, J., Nolan, M., and Davidson, P. M. (2015). The business of death: A qualitative study of financial concerns of widowed older women. BMC women's health, 15(1), 1-10.

Harapan, H., Itoh, N., Yufika, A., Winardi, W., Keam, S., Te, H., Megawati, D., Hayati, Z., Wagner, A. L., and Mudatsir, M. (2020). Coronavirus disease 2019 (COVID-19): A literature review. Journal of Infection and Public Health, 13(5), 667-673. 
Weymouth, R., and Hartz-Karp, J. (2019). Participation in planning and governance: closing the gap between satisfaction and expectation. Sustainable Earth, 2(1), 1-15. 